\title{
The effect of partial replacement of fish meal protein by dietary hydrolyzed fish protein concentrate on the growth performance of orange- spotted grouper epinephelus coioides
}

\begin{abstract}
This study investigated the effect of partial fish meal protein replaced by hydrolyzed fish protein concentrate [HFPC] on the growth performance of orange-spotted group erl. Epinephelus coioides (1.77 $\mathrm{g}$ initial weight) were fed five isonitrogenous [45\%] and isolipidic [11\%] diets containing different levels of HFPC to replace $0,5,10,15$ and $20 \%$ $[0 \mathrm{FS}, 5 \mathrm{FS}, 10 \mathrm{FS}, 15 \mathrm{FS}$ and $20 \mathrm{FS}]$ of fish meal protein, respectively. Each diet was fed to triplicate groups of fish three times a day until satiation for six weeks. The weight gain percentages of fish fed diets containing HFPC to replace 5, 10, and 20\% fish meal protein were significantly $[\mathrm{p}<0.05]$ higher than those of fish fed the control diet. The crude protein, crude lipid and ash contents of muscle of fish fed diets containing HFPC were lower than those of fish fed the control diet. The results indicated that diets included HFPC can improve growth performance of fish, and up to $20 \%$ fish meal protein can be replaced by HFPC in the diets for orange-spotted grouper Epinephelus coioides.
\end{abstract}

Keywords: Fish meal, Hydrolyzed fish protein concentrate, Replacement, Orangespotted grouper
Volume I Issue 2 - 2014

\author{
Sheen SS, Chen CT, Ridwanudin A \\ Department of Aquaculture, National Taiwan Ocean University, \\ Taiwan
}

Correspondence: Sheen SS, Department of Aquaculture, National Taiwan Ocean University, Keelung, Taiwan 20224, Tel: 886224622192; Fax: 88622463।446; Emailshin@mail.ntou.edu.tw

Received: December 04, 2014 | Published: December 15, 2014
Abbrevations: HFPC, Hydrolyzed Fish Protein Concentrate; NFE, Nitrogen Free Extract; ANOVA, A One-Way Analysis of Variance; FCR, Feed Conversion Ratios; ADC, Apparent Digestibility Coefficient

\section{Introduction}

In the recent decades, the interest in grouper aquaculture has been reported to increase rapidly in several Asian countries. ${ }^{1,2}$ As a marine carnivorous fish, grouper require high level protein in the diet, ${ }^{3,4}$ and most of practical feed contain high amount of fish meal as a main protein source. ${ }^{5}$ However, the increasing price of fish meal is the most important concern related to economics and availability of this ingredient in the future, ${ }^{6,7}$ and fish feed industry challenges to reduce dietary fish meal level. Therefore, the replacement of fish meal with alternative protein sources in fish diet is ongoing research priority to fish nutrition. ${ }^{8}$

Many studies have investigated on the use of terrestrial plant and animal by-products as protein sources to partial or total replacement of fish meal in marine carnivorous diets. ${ }^{9-16}$ Deficient amino acids and the presence of anti-nutritional factors are the limiting factors in using of plant protein sources in fish diet, ${ }^{17-20}$ and also the problem associated with animal by-product in fish diet is the quality of these terrestrial animals which depend on the quality of raw material and processing technique. ${ }^{10,21,22}$ However, less attention has been paid to use other protein sources such as hydrolysate fish protein products.

HFPC produced from by-products of the fishery industry. HFPCs generally containing high levels of nutritional value and free amino acids are potential alternative ingredients to replace fish meal in fish feeds..$^{23-25}$ The chemical compositions of HFPC were usually similar to those of the raw materials used. ${ }^{25,26}$ Hydrolysed fish protein products have been extensively studied as dietary ingredients for Salmosalar $\mathrm{L},{ }^{27}$ cobia Rachycentron canadum, ${ }^{28}$ pacu Piaractus mesopotamicus, ${ }^{29}$ African catfish ${ }^{30,31}$ and common carp Cyprinus carpio. ${ }^{32}$ Highly apparent digestibility coefficient [ADC] of protein of sardine silage [95.1\%] in the diets for tilapia was similar with ADC of protein of fish meal [95.8\%]. ${ }^{33}$ The fermented silage had higher protein digestibility than acid silage in the diets for pacu Piaractus mesopotamicus. ${ }^{29}$ The protein digestibility of enzymatic fish silage was higher than acid and bacterial fish silage in the diets for Nile tilapia Oreochromis niloticus. ${ }^{34}$ However, another concern of using HFPC in fish diet is the deficiency of amino acid such as tryptophan due to prolonged autolysis when making this product. ${ }^{23,34}$

A number of studies are also available on the use of ingredients from terrestrial plant ${ }^{35}$ and animal by-products ${ }^{36-40}$ in grouper diets to partially or totally replace fish meal. However, there is no study on the utilization of HFPC as a protein source in grouper diet. The purpose of the present study was to evaluate the effects of HFPC as a partial replacement of fish meal protein in the diets on the growth performance and body composition of orange-spotted grouper Epinephelus coioides.

\section{Materials and methods}

\section{Experimental Diets}

Five isonitrogenous [45\%] and isolipidic [11\%] experimental diets were formulated in the present study. The experimental diets were included $0,2.35,4.68,7.03$ and $9.37 \% \mathrm{HFPC}$ to replace $0 \%[0 \mathrm{FS}], 5 \%$ [5FS], $10 \%$ [10FS], $15 \%$ [15FS] and 20\% [20FS] of fish meal protein. HFPC was obtained from commercial supplier [Scan Pro 35/4, Scan Bio, Trondheim, Norway]. The hydrolysate was conducted by formic acid treatment. The formulation and proximate compositions of diets are given in Table 1. Proximate composition analyses showed that all experimental diets contained $45.9-47.0 \%$ crude protein and $9.4-10.5 \%$ 
crude lipid. Ash content decreased with increasing HFPC in the diets [16.95-14.50\%]

In preparing the experimental diets, all dietary ingredients were first ground to small particle size with hammer mill and then passed through a $250 \mu \mathrm{m}$ mesh sieve. Dry ingredients of experimental diets were mechanically mixed to insure homogeneity. Distilled water was added [approximately $25 \%$ of dry weight] and the mixture blended thoroughly by hand until a consistency for extrusion was achieved. Diets were cold-extruded through a chopper [3.0 $\mathrm{mm}$ die diameter] to produce pellets. The pellets were dried in an air dry oven at $60 \mathrm{oC}$ for 12 hours. The experimental diets were stored at $4 \mathrm{oC}$ in a refrigerator until used [Table 1]

\section{Feeding Trial}

Orange-spotted grouper were obtained from the southern coast of
Taiwan and transported by air, in tightly sealed bags, quarter filled with seawater and inflated with oxygen, enclosed in an insulated container. They were acclimatized to laboratory condition for one week prior to the start of feeding trial. During this period, orange-spotted grouper were fed a control diet $[45.9 \%$ crude protein, and $10.5 \%$ crude lipid] three times a day. At the beginning of experiment, fish were starved $24 \mathrm{~h}$ and $1.77 \mathrm{~g}$ uniform-sized fish randomly distributed into 15 glass aquaria $[57 \times 30 \times 35 \mathrm{~cm}]$ with $10 \mathrm{fish}$ in each aquarium. Each of the five experimental diets was hand-fed gradually to triplicate groups of fish three times a day at 09:00, 16:00 and 21:00 h until satiation for six weeks. Feces and uneaten feed were removed every day, and lost water during cleaning was replaced. Fish in each aquarium were individually weighed every two weeks of the feeding trial to monitor growth performance, and also individually was weighed at the beginning and the end of the feeding trial.

Table I Formulation and proximate composition of experimental diets for orange-spotted grouper Epinepheluscoioides

\begin{tabular}{|c|c|c|c|c|c|}
\hline & \multicolumn{5}{|l|}{ Diets } \\
\hline & OFS & 5FS & IOFS & I5FS & 20FS \\
\hline \multicolumn{6}{|l|}{ Ingredients (\% dry basis) } \\
\hline Fish meal $^{\mathrm{a}}$ & 52 & 49.40 & 46.80 & 44.20 & 41.60 \\
\hline $\mathrm{HFPC}^{\mathrm{b}}$ & 0 & 2.35 & 4.68 & 7.03 & 9.37 \\
\hline Basal mix ${ }^{c}$ & 35 & 35 & 35 & 35 & 35 \\
\hline Oil $^{d}$ & 5.40 & 5.28 & 5.15 & 5.03 & 4.90 \\
\hline$\alpha$-cellulose & 7.60 & 7.98 & 8.37 & 8.74 & 9.13 \\
\hline \multicolumn{6}{|l|}{ Proximate composition (\%) } \\
\hline Moisture & 2.95 & 3.52 & 3.84 & 2.98 & 2.89 \\
\hline Crude protein ${ }^{e}$ & 45.86 & 46.85 & 46.69 & 47.00 & 46.72 \\
\hline Crude lipide & 10.52 & 10.03 & 10.33 & 9.40 & 9.49 \\
\hline Crude fibere & 4.42 & 3.33 & 3.80 & 4.39 & 5.11 \\
\hline Ash $^{\mathrm{e}}$ & 16.95 & $|5.3|$ & 14.80 & 14.68 & 14.50 \\
\hline $\mathrm{NFE}^{\mathrm{e}, \mathrm{f}}$ & 22.25 & 24.48 & 24.38 & 24.53 & 24.18 \\
\hline Gross energy $(\mathrm{Kcal} / \mathrm{l00g})^{\mathrm{e}}$ & 447.90 & 454.00 & 450.25 & 455.60 & 455.00 \\
\hline
\end{tabular}

aFish meal : $63.50 \%$ crude protein and $8.56 \%$ crude lipid.

bHFPC (dry matter): $70 \%$ crude protein, $8 \%$ crude lipid and $12 \%$ ash.

cSquid meal $5 \%$, shrimp meal $10 \%$, yeast $1 \%$, wheat flour $15 \%$, mineral mix $2 \%$ (Bernhart-Tomarelli modified ${ }^{59}$ ) and vitamin mix $2 \%(0.5 \%$ Thiamine $\mathrm{HCl}$, $0.8 \%$ Riboflavin, 2.6\% Niacinamide, 0.1\% D-Biotin, I.5\% Ca-pantothenate, 0.3\% Pyridoxine HCl, 0.5\% Folic acid, I8. I\% Inositol, I2. I\% Ascorbic acid, 3\% Paraaminobenzoic acid, 0.1\% Cyanocobalamine, 0.1\% BHT and $60.3 \% \alpha$-cellulose).

dFish oil: corn oil $=2: 1$.

eExpressed as percent dry weight.

fNFE (Nitrogen free extract): 100 - (\% crude protein $+\%$ crude lipid $+\%$ crude fiber $+\%$ ash).

The feeding trial was conducted in a recirculation seawater system and each aquarium was provided with continuous aeration through an air stone connected to a central air compressor. Water temperature and salinity varied from 27 to $31 \mathrm{oC}$ and from 32 to $35 \mathrm{ppt}$, respectively. A $12 \mathrm{~h}$ light: $12 \mathrm{~h}$ dark photoperiod was maintained to simulate the natural light cycle.

After the termination of feeding trial, all fish from each tank were randomly sampled for proximate analysis. Fish were killed by immersing in ice water. Fish muscle were carefully dissected, dried and then homogenized. The homogenates were mixed into one sample for each diet treatment and analyzed in duplicates.

\section{Proximate Analysis}

The ingredients, experimental diets and fish muscle were analyzed for proximate composition based on the standard method of. ${ }^{41}$ Samples of ingredients, experimental diets and fish muscle were dried to a constant weight at $105 \mathrm{oC}$ to determine moisture. Ash was determined by combustion at $540 \mathrm{oC}$ in a muffle furnace, protein was measured by nitrogen [ $\mathrm{N} \times 6.25]$ using the Kjeldahl system method after an acid digestion using a Kjeldahl system [Kjeldahl system 1002, Tecator, Sweden], and lipid was determined by chloroform and methanol $[\mathrm{C}: \mathrm{M}$ ratio $2: 1, \mathrm{v} / \mathrm{v}]$ extraction procedure according to. ${ }^{42}$ Fiber was determined by using the Fiber tec system M 1020 [FossTecator, Sweden]. Nitrogen free extract [NFE] was determined by differences $[\mathrm{NFE}=100 \%-(\%$ protein $+\%$ lipid $+\%$ ash $+\%$ fiber $)]$. Gross energy of diets was determined by using a bomb calorimeter [IKA calorimeter system C 2000 basic, German].

\section{Data Calculation and Statistical Analysis}

Weight gain percentage and specific growth rate [SGR] were calculated according to the following equations: WG $(\%)=100 \mathrm{x}$ $\left[\mathrm{W}_{t}-\mathrm{W}_{0}\right] / \mathrm{W} 0$ and SGR $\left[\%\right.$ day $\left.^{-1}\right]=100 \mathrm{x}\left[\left(\ln \mathrm{W}_{\mathrm{t}}-\ln \mathrm{W}_{0}\right) / \mathrm{t}\right]$, where $\mathrm{W}_{0}$ is the initial mean body weight $[\mathrm{g}]$, Wt is the final mean body weight $[\mathrm{g}]$ and $\mathrm{t}[\mathrm{day}]$ is the feeding period. 
A one-way analysis of variance [ANOVA] was performed to examine differences in weight gain percentages, SGR and survival among treatments. When a significant difference was observed, a Duncan's new multiple range test was used to compare differences among treatment means. The significant level was set at $p<0.05$ and all statistical analyses were conducted using SAS software program for windows [V.9.3., SAS Institute, Cary, North Carolina, USA].

\section{Results}

All diets were well accepted by fish and consumed aggressively for the duration of the experiment. Survival of fish was greater than $90 \%$ for all treatment diets. Growth performances of orangespotted grouper fed experimental diets are presented in Table 2. The growth performance of orange-spotted grouper fed 5FS, 10FS and 20FS diets were significantly higher than that of grouper fed diet without supplemented with HFPC. The growth performance of fish fed the control diet was not significantly different from that of fish fed 15FS. However, there were no significant differences in weight gain percentage and SGR among fish fed diets containing different levels of HFPC. Feed conversion ratios [FCR] of grouper fed diets containing HFPC were lower than that of grouper fed the control diet.

Table 2 Initial weight, final weight, weight gain, specific growth rate (SGR) and survival of orange-spotted grouper Epinephelus coioides I

\begin{tabular}{lllll}
\hline Diets & Initial weight $(\mathbf{g})$ & Final weight $(\mathbf{g})$ & Weight gain $(\%)$ & SGR $\left(\%\right.$ day $\left.^{-1}\right)$ \\
\hline OFS & $1.77 \pm 0.12$ & $16.91 \pm 0.74^{\mathrm{b}}$ & $858.04 \pm 35.63^{\mathrm{b}}$ & $5.38 \pm 0.09^{\mathrm{b}}$ \\
5FS & $1.77 \pm 0.08$ & $20.25 \pm 1.91^{\mathrm{a}}$ & $1044.03 \pm 58.17^{\mathrm{a}}$ & $5.80 \pm 0.12^{\mathrm{a}}$ \\
IOFS & $1.77 \pm 0.06$ & $19.76 \pm 1.99^{\mathrm{ab}}$ & $1013.00 \pm 83.49^{\mathrm{a}}$ & $5.73 \pm 0.18^{\mathrm{a}}$ \\
I5FS & $1.77 \pm 0.02$ & $19.44 \pm 1.67^{\mathrm{ab}}$ & $981.54 \pm 103.28^{\mathrm{ab}}$ & $5.66 \pm 0.22^{\mathrm{ab}}$ \\
20FS & $1.77 \pm 0.01$ & $19.64 \pm 1.15^{\mathrm{ab}}$ & $1011.60 \pm 66.61^{\mathrm{a}}$ & $5.73 \pm 0.14^{\mathrm{a}}$ \\
\hline
\end{tabular}

'Values are mean $\pm S D$, obtained from three replicates $(n=3)$ with 10 fish for each group.

${ }^{2} \mathrm{FCR}$ (feed conversion ratio) $\mathrm{FCR}=$ feed supply $[\mathrm{g}] /[\mathrm{final}$ body weight $[\mathrm{g}]-$ initial body weight $[\mathrm{g}]]$

Different superscripts in each column indicate significantly different mean values $(p<0.05)$.

Table 3 Muscle proximate analysis of orange-spotted grouper Epinepheluscoioides

\begin{tabular}{|c|c|c|c|c|}
\hline \multirow[t]{2}{*}{ Muscle composition } & \multicolumn{4}{|l|}{ Diets } \\
\hline & OFS & 5FS & IOFS & I5FS \\
\hline Moisture & 78.09 & 77.64 & 77.65 & 77.39 \\
\hline Crude protein* & 76.35 & 74.83 & 74.40 & 74.95 \\
\hline Crude lipid* & 12.44 & 11.99 & 10.29 & 14.13 \\
\hline Ash* & 5.84 & 5.41 & 5.15 & 5.26 \\
\hline
\end{tabular}

*Expressed as percent of dry weight basis.

Partial replacement of fish meal protein by HFPC also affected muscle proximate composition of fish. The ash and water content of muscle of fish fed diets included different levels of HFPC was lower than those of fish fed the control diet. The levels of crude protein and crude lipid of muscle decreased with increasing dietary HFPC levels; however, the trend was slightly fluctuation [Table 3].

\section{Discussion}

The growth performance of orange-spotted grouper fed diets supplemented with HFPC to replace fish meal protein can be improved in this study. The positive effects of inclusion acidic and enzymatic hydrolysate fish protein in the diets have also been reported for Atlantic salmon Salmosalar, ${ }^{43-45}$ Japanese sea bass Lateolabrax japonicas ${ }^{46}$ red seabream Pagrus major ${ }^{47}$ black bass Micropterus salmoides ${ }^{48}$ and common carp Cyprinus carpio. ${ }^{32}$

In the present study, up to $20 \%$ fish meal protein in the diet for Epinephelus coioides could be replaced by HFPC. This finding was similar with ${ }^{49}$ who reported that fish meal protein could be replaced by enzymatic hydrolyzed fish protein up to $25 \%$ in the diet without negative effect on the growth performance of turbot Scophthalmus maximus. The hydrolyzed silage head shrimp meal could replace fish meal protein up to $20 \%$ in African catfish Clarias gariepinus diets. ${ }^{50}$ Tilapia and African catfish fed diets supplemented with 15 to $30 \%$ hydrolysate protein products to replace fish meal protein showed no adverse effects on growth performance. ${ }^{51-53}$ It is referred that hydrolysate fish proteins can be good alternative protein sources to replace dietary fish meal protein.
The growth performances of Atlantic salmon ${ }^{44,45}$ and red seabream ${ }^{47}$ fed diets containing hydrolysate fish protein-based diets were better than those of fish fed the control diet and feed intakes increased with increasing dietary hydrolysate fish protein. In the present study, grouper fed diets containing HFPC showed low levels of FCR. Therefore, we can see that the more diets were fed by grouper, the higher growth performances of grouper were. This indicates that hydrolysate fish protein could act as an attractant to improve palatability of diet. It is well known that hydrolysate fish proteins contain small molecular-weight compounds which have beneficial effects to enhance fish growth and feed utilization. ${ }^{54-57}$ These were also supported by ${ }^{58}$ who reported that di- and tripeptides included in the diets could improve growth and survival of sea bass Dicentrarchus labrax larvae.

The crude protein, crude lipid and ash contents of muscle of orange-spotted grouper fed different level of HFPC were lower than those of muscle of fish fed the control diet. The low level of ash content of muscle of fish fed HFPC was similar to the previous finding in cobia, ${ }^{28}$ red seabream, ${ }^{47}$ black bass ${ }^{48}$ African catfish ${ }^{50,52}$ and Nile tilapia. ${ }^{53}$ However, studies reported that increasing dietary hydrolyzed fish protein increased ash level ${ }^{31,51}$ and lipid contents ${ }^{45,47,52,53}$ of fish muscle. The differences in proximate composition of muscle of fish fed hydrolysate protein-based diets might be due to the different raw materials used for those studies.

In conclusion, the results of the present study showed that diets supplemented HFPC to replace $20 \%$ fish meal protein could improve growth performance of orange-spotted grouper Epinephelus coioides. 


\section{Acknowledgements}

This study was partially supported by grants, 102AS-6.2.1-ST-a9 and 103 AS-14.3.3-ST-a6, from the Council of Agriculture, Executive Yuan, Taiwan, ROC.

\section{Conflicts of interest}

None.

\section{References}

1. Miao S, Tang HC. Bioeconomic analysis of improving management productivity regarding grouper Epinephelus malabaricusfarming in Taiwan. Aquaculture. 2002;211(1-4):151-169.

2. Pierre S, Gaillard S, Prevot-Dalvise N, et al. Grouper aquaculture: Asian success and Mediterranean trials. Aquatic Conservation: Marine Freshwater Ecosystems. 2008;18(3):297-308.

3. Boonyaratpalin M. Nutrient requirements of marine food fish cultured in Southeast Asia. Aquaculture. 1997;151(1-4):283-313.

4. Williams KC. A review of feeding practices and nutritional requirements of postlarval groupers. Aquaculture. 2009;292(3-4):141-152.

5. Mente E, Pierce GJ, Santos MB, et al. Effect of feed and feeding in the culture of salmonids on the marine aquatic environment: a synthesis for European aquaculture. Aquaculture International. 2006;14(5):499-522.

6. Hardy RW. Utilization of plant proteins in fish diets: effects of global demand and supplies of fishmeal Aquaculture Research. 2010;41(5):770-776.

7. Olsen RL, Hasan MR. A limited supply of fish meal: Impact on future increases in global aquaculture production. Trends in Food Science \& Technology. 2012;27(2):120-128

8. Tacon AGJ, Metian M. Global overview on the use of fish meal and fish oil in industrially compounded aqua-feeds: Trend and future prospects. Aquaculture. 2008;285(1-4):146-158.

9. Quartararo N, Allan GL, Bell JD. Replacement of fish meal in diets for Australian snapper, Pagrusauratus. Aquaculture. 1998;166(3-4):279295.

10. Nengas I, Alexis MN, Davies SJ. High inclusion levels of poultry meals and related byproducts in diets for gilthead seabream SparusaurataL. Aquaculture. 1999;179(1-4):13-23.

11. Burel C, Boujard T, Kaushik SJ, et al. Potential of plant-protein sources as fish meal substitutes in diets for turbot (Psetta maxima): growth, nutrient utilization and thyroid status. Aquaculture. 2000;188(3-4):363382.

12. Chou RL, Her BY, Su MS, et al. Substituting fish meal with soybean meal in diets of juvenile cobia Rachycentron canadum. Aquaculture. 2004;229(1-4):325-333.

13. Kaushik SJ, Coves D, Dutto G, et al. Almost total replacement of fish meal by plant protein sources in the diet of marine teleost, the European seabass, Dicentrarchus labrax. Aquaculture. 2004;230(1-4):391-404.

14. Yigit M, Erdem M, Koshio S, et al. Substituting fish meal with poultry by-product meal in diets for black Sea turbot Psettamaeotica. Aquacult Nutr. 2006;12:340-347.

15. Francesco M, Parisi G, Perez-Sanchez J, et al. Effect of high-level fish meal replacement by plant proteins in gilthead sea bream (Sparusaurata) on growth and body/fillet quality traits. Aquaculture Nutrition 2007;13(5):361-372.

16. Rossi W Jr, Davis DA. Replacement of fish meal with poultry byproduct meal in the diet of Florida pompano Trachinotus carolinusL. Aquaculture. 2012;338-341:160-166.
17. Arndt RE, Hardy RW, Sugiura SH, et al. Effect of heat treatment and substitution level on palatability and nutritional value of soy defatted flour in feeds for Coho salmon, Oncorhynchus kisutch. Aquaculture. 1999;180(1-2):129-145.

18. Francis G, Makkar HPS, Becker K. Antinutritional factors present in plant-derived alternate fish feed ingredients and their effects in fish. Aquaculture. 2001;199(3-4):197-227.

19. Tantikitti C, Sangpong W, Chiavareesajja S. Effects of defatted soybean protein levels on growth performance and nitrogen and phosphorus excretion in Asian seabass (Lates calcarifer). Aquaculture. 2005;248(14):41-50.

20. Kaushik SJ, Seiliez I. Protein and amino acid nutrition and metabolism in fish: current knowledge and future needs. Aquaculture Research. 2010;41(3):322-332.

21. Bureau DP, Harris AM, Cho CY. Apparent digestibility of rendered animal protein ingredients for rainbow trout (Oncorhynchus mykiss). Aquaculture. 1999;180(3-4):345-358.

22. Kureshy N, Davis DA, Arnold CR. Partial replacement of fish meal with meat-and-bone meal, flash-dried poultry by-product meal, and enzyme-digested poultry by-product meal in practical diets for juvenile red drum. North American Journal of Aquaculture. 2000;62(4):266-272.

23. Hertrampf JW, Piedad-Pascual F. Handbook on ingredients for aquaculture feeds. Kluwer Academic Publishers, Netherlands. 2000.

24. Vidotti RM, Viegas EMM, Carneiro DJ. Amino acid composition of processed fish silage using different raw materials. Animal Feed Science and Technology. 2003;105(1-4):199-204.

25. Mach DTN, Nortvedt R. Chemical and nutritional quality of silage made from raw or cooked lizard fish (Saurida undosquamis) and blue carb (Portunus pelagicus). Journal of the Science Food and Agriculture. 2009;89(15):2519-2526.

26. Espe M, Lied E. Fish silage prepared from different cooked and uncooked raw materials: Chemical changes during storage at different temperatures. Journal of the Science Food and Agriculture. 1999;79(2):327-332.

27. Espe M, Sveier H, Hogoy I, et al. Nutrient absorption and growth of Atlantic salmon (Salmo salarL.) fed fish protein concentrate. Aquaculture. 1999;174(1-2):119-137.

28. Mach DTN, Nortvedt R. Free amino acid distribution in plasma and liver of juvenile cobia (Rachycentron canadum) fed increased levels of lizardfish silage. Aquaculture Nutrition. 2011;17(2):644-656.

29. Vidotti RM, Carneiro DJ, Viega EMM. Acid and fermented silage characterization and determination of apparent digestibility coefficient of crude protein for pacu (Piaractus mesopotamicus). Journal of the World Aquaculture . 2002;33(1):57-62.

30. Fagbenro O, Jauncey K. Growth and protein utilization by juvenile catfish (Clarias gariepinus) fed dry diets containing co-dried lacticacid-fermented fish-silage and protein feedstuffs. Bioresource Technology. 1995;51(1):29-35.

31. Soltan MA, Hanafy MA, Wafa MIA. An evaluation of fermented silage made from fish by-product as a feed ingredient for African catfish (Clarias gariepinus). Global Veterinaria. 2008;2(2):80-86.

32. Ramasubburayan R, Iyapparaj P, Subhashini KJ, et al. G.Characterization and nutritional quality of formic acid silage developed from marine fishery waste and their potential utilization as feed stuff for common carp Cyprinus carpio fingerlings. Turkish Journal of Fisheries and Aquatic Sciences. 2013;13:281-289.

33. Goddard JS, Al Yahyai SS. Chemical and nutritional characteristics of dried sardine silage. Journal of Aquatic Food Product Technology. 2001;10(4):39-50. 
34. Borghesi R, Portz L, Oetterer M, et al. Apparent digestibility coefficient of protein and amino acids of acid, biological and enzymatic silage for Nile tilapia (Oreochromis niloticus). Aquaculture Nutrition. 2008;14(3):242-248.

35. Shapawi R, Ebi I, Yong A, et al. Soybean meal as a source of protein in formulated diets for tiger grouper, Epinephelus fuscoguttatusjuvenile. Part II: Improving diet performances with phytase supplementation. Agricultural Sciences. 2013;4:19-24.

36. Millamena OM, Golez NV. Evaluation of processed meat solubles as replacement for fish meal in diet for juvenile grouper Epinephelus coioides (Hamilton). Aquaculture Research. 2002;32(Supplements1):281-287.

37. Millamena OM. Replacement of fish meal by animal by-product meals in a practical diet for grow-out culture of grouper Epinephelus coioides Aquaculture. 2002;204:75-84.

38. Shapawi R, Ng WK, Mustafa S. Replacement of fish meal with poultry by-product meal in diets formulated for the humpback grouper, Cromileptes altivelis. Aquaculture. 2007;273(1):118-126.

39. Wang Y, Li K, Han H, Potential of using a blend of rendered animal protein ingredients to replace fish meal in practical diets for malabar grouper (Epinephelus malabaricus). Aquaculture. 2008;281(1-4):113117.

40. Li K, Wang Y, Zheng ZX, et al. Replacing Fish Meal With Rendered Animal Protein Ingredients in Diets for Malabar Grouper, Epinephelus malabaricus, Reared in Net Pens. Journal of the World Aquaculture Society. 2009;40(1):67-75.

41. AOAC (Association of Official Analytical Chemists). Official Methods of Analysis. (14th edn), AOAC Arlington, USA. 1984.

42. Folch J, Lees M, Stanley GHS. A simple method for the isolation and purification of total lipids from animal tissues. $J$ Biol Chem. 1957;266(1):497-509.

43. Berge GM, Storebakken T. Fish protein hydrolyzate in starter diet for Atlantic salmon (Salmosalar) fry. Aquaculture. 1996;145(1-4):205212.

44. Refstie S, Olli JJ, Standal H. Feed intake, growth, and protein utilization by post-smolt Atlantic salmon (Salmosalar) in response to graded levels of fish protein hydrolysate in the diet. Aquaculture. 2004;239(1-4):331349.

45. Hevroy EM, Espe M, Waagbo R, et al. Nutrient utilization in Atlantic salmon (Salmosalar L.) fed increased levels of fish protein hydrolysate during a period of fast growth. Aquaculture Nutrition. 2005;11(4):301313.

46. Liang M, Wang J, Chang Q, et al. Effect of different levels of fish protein hydrolysate in the diet on the nonspecific immunity of Japanese sea bass, Lateolabrax japonicus (Cuvieret Valenciennes, 1828). Aquac Res. 2006;37:102-106.
47. Bui H.T.D, Khosravi S, Fournier V, et al. Growth performance, feed utilization, innate immunity, digestibility and disease resistance of juvenile red seabream (Pagrus major) fed diets supplemented with protein hydrolysates. Aquaculture. 2014;418-419:11-16.

48. De Arruda LF, Borghesi R, Portz L, et al. Fish silage in black bass (Micropterus salmoides) feed as an alternative to fish meal. Brazilian Archives of Biology and Technology. 2009;52:1261-1266.

49. Oliva-Teles A, Cerqueira AL, Goncalves P. The utilization of diets containing high levels of fish protein hydrolysate by turbot (Scophthalmus maximus) juveniles. Aquaculture. 1999;179(1-4):195-201.

50. Nwanna LC, Balogun AM, Ajenifuja YF, et al. Replacement of fish meal with chemically preserved shrimp head in the diets of African catfish, Clarias gariepinus Food, Agriculture and Environment. 2004;2(1):79-83.

51. Plascencia Jatomea M, Olvera-Novoa MA, Arredondo-Figueroa JL, et al. Feasibility of fishmeal replacement by shrimp head silage protein hydrolysate in Nile tilapia (Oreochromis niloticus L) diets. Journal of the Science of Food and Agriculture. 2002;82(7):753-759.

52. Nwanna LC. Nutritional value and digestibility of fermented shrimp head waste meal by African catfish Clarias gariepinus. Pakistan Journal of Nutrition. 2003;2(6):339-345.

53. Leal ALG, De Castro PF, De Lima JPV, et al. Use of shrimp protein hydrolysate in Nile tilapia (Oreochromis niloticus, L.) feeds. Aquaculture International. 2010;18(4):635-646.

54. Liaset B, Lied E, Espe M. Enzymatic hydrolysis of by-products from the fish-filleting industry; chemical characterization and nutritional evaluation. Journal of the Science of Food and Agriculture. 2000;80(5):581-589.

55. Aksnes A, Hope B, Jonsson E, et al. Size-fractionated fish hydrolysate as feed ingredient for rainbow trout (Oncorhynchus mykiss) fed high level protein diets.I: Growth, growth regulation and feed utilization. Aquaculture. 2006;261(1):305-317.

56. Aksnes A, Hope B, Hostmark O, et al. Inclusion of size fractionated fish hydrolysate in high plant protein diets for Atlantic cod, Gadusmorhua. Aquaculture. 2006;261(3):1102-1110.

57. Zheng K, Liang M, Yao H, et al. Effect of dietary fish protein hydrolysate on growth, feed utilization and IGF-I levels of Japanese flounder (Paralichthys olivaceus). Aquaculture Nutrition. 2012;18(3):297-303.

58. Zambonino-Infante JL, Cahu CL, Peres A. Partial substitution of di-and tripeptides for native proteins in sea bass diet improves Dicentrarchus labraxlarval development. J Nutr. 1997;127(4):608-614.

59. Bernhart FW,Tomarelli RM. A salt mixture supplying the National Research Council estimates of mineral requirements of the rat. J Nutr. 1966;89(4):495-500. 